\title{
The Toxicity of Cooking Oil Fumes on Human Bronchial Epithelial Cells Through ROS-Mediated MAPK, NF-KB Signaling Pathways and NLRP3 Inflammasome
}

\author{
Xiangyu Cao \\ Liaoning University \\ Mingyang Fu \\ Liaoning University \\ Jingyi Miao \\ Liaoning University \\ Yueling Sun \\ Liaoning University
}

Rugang Zhu

Liaoning University

Chengying Liu

Liaoning University

Ruochen Bi

Liaoning University

Shuai Wang

Liaoning University

Jianli Liu ( $\square$ liujianli@Inu.edu.cn )

Liaoning University https://orcid.org/0000-0002-9256-6137

\section{Research Article}

Keywords: Cooking oil fumes, Beas-2B cells, NF-kB signaling pathway, MAPK signaling pathway, Oxidative stress, Inflammation.

Posted Date: June 28th, 2021

DOl: https://doi.org/10.21203/rs.3.rs-604026/v1

License: (a) This work is licensed under a Creative Commons Attribution 4.0 International License. Read Full License 


\section{Abstract}

Cooking oil fumes (COFs) are main pollutants in kitchen and indoor air, which threaten human health. Exposure to COFs can cause respiratory diseases and impair pulmonary function. To investigate the toxicity of COFs on human bronchial epithelial cells (Beas-2B) and explore the underlying mechanisms, MTT assay was conducted to detect the viability of Beas-2B. Intracellular reactive oxygen species (ROS) levels and nitric oxide (NO) levels were determined with DCFH-DA assay and DAF-FM assay. The expression of genes involved in inflammation were measured with quantitative real-time PCR (qRT-PCR). The phosphorylation and the expression of proteins related to Mitogen-activated protein kinase (MAPK), NF-KB signaling pathways were measured with western blot. Our results revealed that COFs decreased Beas-2B cells viability, increased the ROS levels and NO levels in cells and induced apoptosis in Beas-2B cells. The results of qRT-PCR and western blot showed that the expression of NLRP3, p65, iNOS, IL-1 $\beta$, and the factors related to oxidative stress and inflammation increased, NF-KB signaling pathway and MAPK signaling pathway were activated. This study provided some useful information to alleviate the toxicity of COFs and revealed the possible mechanism for the damage on respiratory system induced by COFs.

\section{Introduction}

With the rapid development of urbanization, indoor activities play a crucial role in various social activities and indoor pollution comes into our vision gradually (Jonathan M. Samet 1993). Indoor air pollution, as a kind of indoor pollution, has been recognized as a major public health problem (B. Berglund 1992; Smith 2002). Previous research has shown that nearly 3 billion people around the world were exposed to poor indoor air quality caused by heating, lighting and the burning of coal for cooking (Wang et al. 2018). Approximately 4.3 million people died from the exposure of indoor air pollution every year (GonzalezMartin et al. 2021). The extent and scope of indoor air pollution in developing countries are much more critical than that in developed countries (Ellegard 1997). Cooking, as main human activity, is one of the most common sources of indoor air pollution and can release a lot of pollutants (Ellegard 1997; Sofuoglu et al. 2015; Wang et al. 2018).

COFs pollution produced by cooking usually includes ketones, aldehydes, hydrocarbons, fatty acids, alcohols, aromatic compounds, esters, heterocycles, and lactones is a serious health risk in china due to the cooking manners (Ding et al. 2020; Lee and Gany 2013). In China alone, the number of people exposed to COFs in 2018 has reached to 240 million and most of whom were middle-aged women (Liu et al. 2020). Women exposed to COFs are at higher risk for chronic bronchitis, for pregnant women, such exposure can also affect the fetus and increase the risks of adverse birth outcomes (Hou et al. 2018; Vavalà et al. 2014; Zhu et al. 2019). Studies have shown that exposure to COFs increased the risk of respiratory diseases, such as airway infection, chronic obstructive pulmonary disease, tuberculosis and asthma (Allen L. Robinson 2006; Sjaastad et al. 2010; Sjaastad and Svendsen 2009; Svendsen et al. 2002). In addition, cardiovascular disease, abnormal pregnancy and cervical cancer are also related to COFs (Anderson 1979; Kirk R Smith 2000). The occurrence of these diseases may be related to cytotoxic 
damage caused by COFs, it has been reported that the use of ventilation equipment can reduce the risk of cardiopulmonary death to $40 \%$ within five years (Ma et al. 2021).

It has been reported that the major compound contained in COFs can affect ROS and induce oxidative DNA damage in human lung carcinoma cells (Wu and Yen 2004). The apoptotic effect of COFs in fetal lung type II-like epithelium cells was investigated, which revealed that COFs induced apoptotic via mitochondrial intrinsic apoptosis pathway (Che et al. 2014). Trans, trans-2,4-decadienal (tt-DDE), a composition of cooking oil fumes, could induce oxidative stress and endoplasmic reticulum stress in human corneal epithelial cells (Yan et al. 2020). But the toxicity of COFs on Beas-2B has rarely been reported.

The purpose of this study was to investigate the toxicity of COFs on Beas-2B cells, explore the signaling pathways involved inflammation and oxidative stress and provide some experimental basis for studying the cytotoxic mechanism of COFs on respiratory system.

\section{Materials And Methods}

\section{Cooking oil fumes}

COFs samples were collected by referring to Ding et al (Ding et al. 2020). Briefly, The COFs was produced from heating peanut oil $(200 \mathrm{~mL})$ by an electric heater in iron pan and the temperature was kept at the smoke point $\left(280 \pm 10^{\circ} \mathrm{C}\right)$. The fumes were collected into a brown bottle for preservation and stored at $-80^{\circ} \mathrm{C}$. Different concentrations of COFs were dissolved in dimethyl sulfoxide (DMSO) when used.

\section{Cells and culture conditions}

Beas-2B cells were purchased from Cell Bank of Type Culture Collection of Chinese Academy of Sciences (Shanghai, China) and cultured in high glucose DMEM (Invitrogen, Carlsbad, CA, USA) supplemented with $100 \mathrm{U} / \mathrm{mL}$ penicillin (C0222, Beyotime, Shanghai, China), 10\% fetal bovine serum (FBS, Gibco, New York, $\mathrm{NY}, \mathrm{USA}$ ) and $100 \mu \mathrm{g} / \mathrm{mL}$ streptomycin (C0222, Beyotime, Shanghai, China) at $37^{\circ} \mathrm{C}$ in $5 \% \mathrm{CO}_{2}$.

\section{Cell viability assay}

Beas-2B cells were seeded in 12-well plates at density of $3 \times 10^{5}$ cells/well, treated with COFs at concentration of $200 \mu \mathrm{g} / \mathrm{mL}$ for $12 \mathrm{~h}, 24 \mathrm{~h}$ and $48 \mathrm{~h}$ and observed with electron microscope (Olympus CX22LED microscope 10xmagnification, Olympus Corporation, Tokyo, Japan) (Liu et al. 2018). The cells viability was detected with MTT assay (Cao et al. 2021). Briefly, Beas-2B cells were seeded at the density of $1 \times 10^{4}$ cells per well in 96-well plate, then the cells were cultured in a humidified atmosphere of $5 \% \mathrm{CO}_{2}$ at $37^{\circ} \mathrm{C}$ (Lab-Line $\mathrm{CO}_{2}$ Incubator, Merlose Park, USA) and treated with COFs $(100,150,200,250,300,350$, $400,600,800 \mu \mathrm{g} / \mathrm{mL}$ ) for $24 \mathrm{~h}$. Thiazolyl blue tetrazolium bromide (MTT) was added to each well. The absorption at $490 \mathrm{~nm}$ was measured with microplate reader (Varioskan® Flash, Thermo Fisher Scientific 
Inc.), the survival rate was calculated with $O D$ experimental group $/ O D$ control group $\times 100 \%$ (Park and Park 2009).

\section{Apoptosis assay}

After $24 \mathrm{~h}$ exposure to COFs $(200,400,600 \mu \mathrm{g} / \mathrm{mL})$, Beas-2B cells were digested with trypsin without EDTA, washed with $1 \mathrm{~mL}$ PBS twice and centrifuged $5 \mathrm{~min}$ at $1000 \mathrm{rpm}$. According to the manufacturer's protocols, apoptosis was measured with double stained with Annexin-V-FITC apoptosis detection kit and propidium (PI) (eBioscience, CA, USA). Briefly, $100 \mu \mathrm{L}$ binding buffer, $1 \mu \mathrm{L}$ Annexin V-FITC, and $1 \mu \mathrm{L} \mathrm{PI}$ staining solution were added to Beas-2B cells in 6-well plates, the cells incubated at room temperature for 5 min and the apoptosis was detected with a flow cytometry (BD, FACS Cantoll) (Wang et al. 2019).

\section{mRNA expression measurement}

Total cellular RNA was extracted from Beas-2B cells with RNA isolation kit (Sigma-Aldrich) according to the manufacturer's instructions. The mRNA was transcribed into cDNA with cDNA synthesis kit. Then, qRT-PCR was conducted by using the SYBR Premix Ex Taq (Tli RNaseH Plus) with Applied Biosystems 7500 Real-Time PCR system (Appbice Applied Biosystems Trading Co., Ltd., Shanghai, China). The PCR thermocycling conditions were as follows: denaturation at $95^{\circ} \mathrm{C}$ for 40 seconds followed by 40 cycles of $95^{\circ} \mathrm{C}$ for 10 seconds and $60^{\circ} \mathrm{C}$ for 35 seconds (Zhong et al. 2019). The primer pairs for human IL-6, iNOS, ICAM-1, IL-1 $\beta$, IL-8, COX-2, NLRP3, CRP, TNF-a, IL-17, IL-18 and $\beta$-actin were shown in table 1.

Table 1 Sequences of primers and probes used in the present study

\begin{tabular}{|c|c|c|c|}
\hline Gene & Primer Forward $05 \rightarrow 3 \square$ & Primer Reverse $[5 \rightarrow 3 \square$ & Product \\
\hline TNF-a & AGGACGAACATCCAACCTTCCCAA & TTTGAGCCAGAAGAGGTTGAGGGT & 92 \\
\hline iNOS & TGCAGACACGTGCGTTACTCC & GGTAGCCAGCATAGCGGATG & 130 \\
\hline COX-2 & TTCAAATGAGATTGTGGGAAAATTGCT & AGATCATCTCTGCCTGAGTATCTT & 146 \\
\hline IL-1 $\beta$ & TCCAGGGACAGGATATGGAG & TCTTTCAACACGCAGGACAG & 133 \\
\hline IL-6 & ATGAACTCCTTCTCCACAAGCGC & GAAGAGCCCTCAGGCTGGACTG & 166 \\
\hline IL-8 & AGCTCTGTGTGAAGGTGCAG & AATTTCTGTGTTGGCGCAGT & 148 \\
\hline ICAM-1 & AGC TTC TCC TGC TCT GCA AC & GTC TGC TGG GAA TTT TCT GG & 146 \\
\hline NLRP3 & СTTCCTTTCCAGTTTGCTGC & TCTCGCAGTCCACTTCCTTT & 212 \\
\hline CRP & GGGCCCTTCAGTCCTAATGTC & TTCGCCTTGCACTTCATACTT & 156 \\
\hline$\beta$-Actin & ACCGCCGAGACCGCGTCCGCCCCGC & TGTTGCCGAGGCCGTACA & 133 \\
\hline IL-17 & TGGGAAGACCTCATTGGTGT & GGATTTCGTGGGATTGTGAT & 84 \\
\hline IL-18 & AGTCAGCAAGGAATTGTCTCC & GAAGCGATCTGGAAGGTCTG & 135 \\
\hline
\end{tabular}




\section{Measurement of intracellular ROS}

The levels of ROS were measured with the fluorescent probe 2', 7'-dichlorofluorescein diacetate (DCFHDA) (KeyGen Biotech, Jiangsu, China). In short, Beas-2B cells were treated with COFs $(200,400,600,800$ $\mu \mathrm{g} / \mathrm{mL}$ ) for $24 \mathrm{~h}$, then washed with PBS once and probed with $10 \mathrm{mM} \mathrm{DCFH-DA}$ for $30 \mathrm{~min}$ at $37^{\circ} \mathrm{C}$. The positive fluorescent signals were imaged under inverted fluorescence microscope (Park et al. 2008).

\section{Measurement of intracellular NO}

Intracellular NO was measured with the NO-specific cell-penetrable fluorescent probe 3-Amino, 4aminomethyl-2, 7-difluorescein, diacetate (DAF-FM) (KeyGen Biotech, Jiangsu, China). Briefly, Beas-2B cells were seeded in 12-well plates at a density of $1 \times 10^{6}$ cells/well and treated with different concentrations COFs $(200,400,600,800 \mu \mathrm{g} / \mathrm{mL})$ for $24 \mathrm{~h}$. After removal supernatant, the cells was washed once and probed with $10 \mathrm{mM} \mathrm{DAF-FM} \mathrm{for} 35 \mathrm{~min}$ at $37^{\circ} \mathrm{C}$. The positive fluorescent signals were observed under inverted fluorescence microscope (× 10) (Li et al. 2020).

\section{Cell signaling pathway analysis}

Western blot analysis was carried out according to our previous study (Cao et al. 2020b). After treatment with $\operatorname{COFs}(0,200,400,600 \mu \mathrm{g} / \mathrm{mL})$ for $24 \mathrm{~h}$, Beas-2B cells were harvested and lysed, total protein extracts and nuclear extracts were prepared with total protein and nuclear protein extraction kits. Then the protein concentration was measured by BCA method. Protein samples were separated by $10 \%$ SDS-PAGE gels and transferred to PVDF membranes according to standard electroblotting procedures. After blocked with $5 \%$ non-fat milk for $1 \mathrm{~h}$, the membrane was incubated with anti-Bax, anti-Bcl-2, anti-cleaved caspase1, anti-cleaved caspase-3, anti-IKB, anti-p-IKB, anti-p65, anti-PCNA, anti- $\beta$-actin, anti-JNK, anti-ERK, antip38, anti-p-JNK, anti-p-ERK, anti-p-p38 monoclonal antibodies (at 1:2000 dilutions), then incubated with secondary antibodies. Finally, bands were observed by using an enhanced chemiluminescence kit. The relative level of total protein was normalized to $\beta$-actin and the relative level of nuclear protein was normalized to PCNA (Cao et al. 2020a; van der Stel et al. 2020).

\section{Statistical analysis}

The data were presented as means \pm standard deviation (SD) at least three independently performed experiments. The date analyses were performed with one-way analysis of variance (ANOVA) with SPSS 21.0 (IBM SPSS, Armonk, NY, USA). $P<0.05$ and $P<0.01$ revealed statistical significance.

\section{Results}

\section{Cytotoxicity of COFs on Beas-2B cells}

Morphological changes of Beas-2B cells were observed under the phase contrast microscope. After COFs $(200 \mu \mathrm{g} / \mathrm{mL})$ treatment, the shape of cells changed from tiled to round, and even floating, indicating that the decreased viability of Beas-2B cells was mainly attributable to cells death (Fig. 1A). 
The toxicity of COFs $(100,150,200,250,300,350,400,600,800 \mu \mathrm{g} / \mathrm{mL})$ on Beas-2B cells was evaluated by MTT assay. As shown in Fig. 1B, with the increasing concentration of COFs, the cell viability decreased significantly and showed a dose-manner $(p<0.01)$. Moreover, under the treatment of COFs at the concentration of $600 \mu \mathrm{g} / \mathrm{mL}$ of COFs, approximately $50 \%$ decrease of cell viability was observed after 24 $\mathrm{h}$ in comparison with the group of control group, and 200,400,600 $\mathrm{gg} / \mathrm{mL}$ COFs were selected for the subsequent experiments.

\section{Oxidative stress induced by COFs in Beas-2B cells}

The accumulation of ROS can reflect the degree of oxidative stress and play a key role in oxidative damage (Deanfield et al. 2007; Li et al. 2020). The effects of COFs on ROS production were detected with DCFH-DA fluorescence probe. As shown in Fig. 2, after the cells were treated with different concentrations of COFs $(200,400,600 \mu \mathrm{g} / \mathrm{mL})$, with the increase of COFs concentration, the fluorescence intensity was $1.54,2.04$ and 2.51 times compared with the control group respectively. These results revealed that ROS levels in the cells increased in a dose-dependent manner $(p<0.01)$.

\section{Inflammation induced by COFs in Beas-2B cells}

The NO concentration can be regarded as an indicator of inflammatory reaction (Giuseppe Cirino 2006). As shown in Fig. 3, the fluorescence intensity in $\operatorname{COFs}(200,400,600 \mu \mathrm{g} / \mathrm{mL})$ treatment groups were 1.21, 1.33 and 2.03 times compared to the control group respectively. With the increase of COFs concentration, NO levels of COFs treatment groups increased significantly $(p<0.01)$, which suggested that the inhalation of COFs might lead to inflammation.

\section{Apoptosis induced by COFs in Beas-2B cells}

The apoptosis ratio was detected with flow-cytometry assay (Dhib et al. 2017). As shown in Fig. 4, with the increase of COFs concentration $(200,400,600 \mu \mathrm{g} / \mathrm{mL})$, apoptosis ratios were $10.85 \pm 1.1 \%, 19.7 \pm$ $1.3 \%$, and $24.6 \pm 1.8 \%$ respectively, which were significantly higher than that in the control group (5.6 \pm $1.4 \%)$. Moreover, with the increasing concentrations of COFs, the percentages of apoptosis cells increased significantly and showed a dose dependent manner. These results indicated that Beas-2B cells proliferation was inhibited and apoptosis was activated after the treatment of COFs.

\section{mRNA expression induced by COFs in Beas-2B cells}

After the treatment of COFs at $200 \mu \mathrm{g} / \mathrm{mL}$, the levels of NLRP3, p65, iNOS, TNF-a, COX2, CRP, ICAM-1区IL13囚IL-6, IL-17, IL-8 and IL-18 in Beas-2B cells were measured with quantitative real-time PCR (qRT-

PCR) (Cao et al. 2019). As shown in Fig. 5, the mRNA expression levels of those genes increased after the treatment of COFs at $200 \mu \mathrm{g} / \mathrm{mL}$ compared with the control group $(p<0.01)$.

It is known that iNOS plays an important role in inflammation and infection (Maggie Bargouti 2009). The result showed that the expression level of iNOS increased significantly $(p<0.01)$ after $200 \mu \mathrm{g} / \mathrm{mL}$ COFs 
treatment. In addition, the expression of NLRP3, IL-1 $\beta$, IL-17 and other inflammatory factors were also increased $(p<0.01)$ (Fig. 5) (Pinkerton et al. 2017; William Y. Park and David R. Park 2001).

\section{Apoptosis-related proteins expression induced by COFs in Beas-2B cells}

To further investigate the possible mechanism of apoptosis, the expression of $\mathrm{Bcl}$-2-associated $\mathrm{X}$ (Bax), B-cell lymphoma-2 (Bcl-2), cleaved caspase-3 and cleaved caspase-1 were detected (Wang et al. 2017). Compared with the control group, with the increase of COFs $(200,400,600 \mu \mathrm{g} / \mathrm{mL})$, the ratio of $\mathrm{Bax} / \mathrm{Bcl}-2$ increased significantly $(p<0.01$ ) (Fig. 6). When the concentration of COFs was $400 \mu \mathrm{g} / \mathrm{mL}$ and more, the levels of cleaved caspase- 1 and cleaved caspase-3 proteins were increased compared with the control group significantly $(p<0.01)$. Furthermore, the level of cleaved caspase-3 in $600 \mu \mathrm{g} / \mathrm{mL}$ COFstreated group was 2.51 times compared with the control group $(p<0.01)$. These results showed that COFs increased the ratio of $\mathrm{Bax} / \mathrm{Bcl}-2$, the expression of cleaved caspase- 3 and cleaved caspase- 1 and induced apoptosis in Beas-2B cells.

\section{Effect of COFs on the MAPK signaling pathway}

In order to further study the oxidative stress pathway mediated by COFs, the phosphorylation of extracellular signal-regulated kinase extracellular signal-regulated kinase (ERK), c-Jun N-terminal kinase (JNK) and p38 MAPK were studied. As shown in Figure. 7A, with the increasing concentration of COFs $(200,400,600 \mu \mathrm{g} / \mathrm{mL})$, the ratio of $p$-ERK/ERK showed significant increase in all the concentrations, the ratio of $p-J N K / J N K$ showed significant difference in the concentration of $600 \mu \mathrm{g} / \mathrm{mL}(p<0.01)$, while $p$ p38/p38 significantly increased in the groups of $400 \mu \mathrm{g} / \mathrm{mL}$ and $600 \mu \mathrm{g} / \mathrm{mL}$ compared with the control group respectively (Figure. 7B).

\section{Effect of COFs on the NF-KB signaling pathway}

The expressions of p65 and IKB in COFs $(200,400,600 \mu \mathrm{g} / \mathrm{mL})$ groups were measured to assess the contribution of the NF-KB pathway to the inflammation effect on Beas-2B. 200, 400, $600 \mu \mathrm{g} / \mathrm{mL}$ COFs upregulated the rate of $p-I_{k} B / I_{k B}$ significantly $(p<0.01)$ (Fig. 8). Furthermore, it could be seen that with the increase of COFs concentration, the expression of p65 in nucleus increased $(p<0.01)$ and the change of total p65 was not significant, indicating that NF-kB signaling pathway was activated.

\section{Discussion}

Lung is vulnerable and sensitive to the exposure to air pollutants. According to a Norwegian survey, employees in restaurant exposed to oil fumes were more likely to die from respiratory diseases such as asthma and emphysema (Svendsen et al. 2002). Exposure to COFs increased the probability of acute respiratory infection in children according to a study in Thailand (Juntarawijit and Juntarawijit 2019). A longitudinal study in Chinese military cooks revealed that exposure to COFs caused oxidative DNA damage and lipid peroxidation (Lai et al. 2013). Lungs of mice after inhalation of COFs exhibited diffuse cellulose exudation from alveolar and bronchus, severe hemorrhage and moderate interstitial 
lymphoplasmacytic infiltration (Wu et al. 2004). However, the cytotoxicity induced by COFs in Beas-2B cells has rarely been reported. In this study, the effect of COFs on oxidative stress, inflammation and apoptosis was explored, and the preliminary mechanism of COFs toxicity on Beas-2B cells was investigated.

Oxidative stress is a common manifestation of cell damage (Lee et al. 2013). ROS produced by environmental factors can cause nuclear and mitochondrial damage, cell metabolism dysfunction, inflammation and apoptosis (Aschauer et al. 2015; D. L. Carlisle 2000; Son et al. 2010). After COFs treatment, the accumulation of ROS in Beas-2B cells was significantly increased, which was similar to the damage of deoxynivalenol on HT-29 cells (Guo et al. 2021a). The MAPK signaling pathway is closely related to oxidative stress and promotes the process of cell apoptosis, containing the ERK, JNK and p38 MAPK (Ebegboni et al. 2019). ROS accumulation can active MAPK pathway and induce oxidative stress (Cao et al. 2021). The phosphorylation of ERK, JNK and p38 was upregulated significantly after COFs treatment, suggesting that the MAPK signaling pathway in BEAS-2B cells were activated, which was in consistence with the mechanism about the toxicity of copper in mice (Guo et al. 2021b). Therefore, the mechanism of oxidative stress induced by COFs may be the activation of MAPK signaling pathways.

Inflammation is the primary factor to evaluate the effect of particles in the air on human health (Yao et al. 2021). NF-KB (p65), as a downstream target of p38 MAPK, plays a key role in cell proliferation, apoptosis and inflammatory (Wang et al. 2020). Inactive p65 usually remains in the cytoplasm and activated p65 is usually transported to the nucleus to perform functions (Gholinejad et al. 2019). Expression of iNOS is closely related with the upregulation of p65 and can produce NO which aggravates the inflammatory in cells (Nathan and Ding 2010; Park et al. 2005). COFs treatment upregulated the mRNA expression of iNOS, increased the concentration of NO and induced inflammatory in BEAS-2B cells and this result was same as the mechanism of Toll-like receptor 7 (TLR-7) in B-cell chronic lymphocytic leukemia (B-CLL) cells (Hammadi et al. 2008). C-reactive protein (CRP) is an acute phase protein and plays an important role in inflammation and infection when the body is stimulated by negative effects such as microbial invasion or tissue damage (Schlereth et al. 2014). Our results showed that the concentration of NO increased, inflammatory reaction occurred and inflammatory factor IL-1 $\beta$, IL-6, IL-8, IL-17, IL-18, TNF-a and CRP were upregulated after COFs treatment, and this result was consistent with the inflammation induce by PM 2.5 (Geng et al. 2019). NLRP3 is the most typical and widespread inflammation in pulmonary inflammatory diseases (Cao et al. 2020b). The activation of NLRP3 inflammatory complex is important to fight against respiratory tract infection, however, over activation may lead to serious diseases (Pinkerton et al. 2017). p65 is an important transcription factor regulating cell growth, proliferation, apoptosis and carcinogenesis (Liu et al. 2018). It has been reported that cigarette smoke could increase the NLRP3 inflammatory complex and activate NF-KB pathway in THP-1 cells (Mehta and Dhawan 2020). In this study, the distribution of p65 in the nucleus increased and the phosphorylation of IKB increased after COFs treatment, and this result was consistent with the toxicity induce by acrylamide in HepG2 cells (Bo et al. 2020). the mechanism of COFs induced inflammatory response of Beas-2B cells may be to activate NF-KB signaling pathway. 
Apoptosis is programmed cell death and plays an important role in maintaining cell homeostasis (Ebegboni et al. 2019). Apoptosis is also regulated by many genes, the $\mathrm{Bcl}-2$ is a potent inhibitor of apoptosis and plays a regulatory role in the process of cell apoptosis (Krishnaswamy Kannan 2000). The proportion of pro-apoptotic members to the level of Bax in mitochondria is closely related to cell survival or apoptosis (Ingo Schmitz 2000). The ratio of Bcl-2 to Bax determines the cell's life and death, Bcl-2 family proteins transfer from the cytoplasm to the mitochondrial membrane and mediate the activation of caspase, mediating the mitochondrial endogenous apoptosis pathway (Cao et al. 2021; Yang et al. 2019). It has been reported that crotonaldehyde could induce Beas-2B cells apoptosis by regulating the expression of caspase family proteins (Wang et al. 2019). In this experiment, COFs could significantly upregulate the expression of Bax, cleaved caspase-1, cleaved caspase-3, decrease the expression of Bcl-2, the same mechanism was also addressed in the apoptosis caused by chlorogenic acid in chondrocyte cells (Kulyar et al. 2021). COFs could induce apoptosis by regulating the mitochondrial apoptosis pathway.

\section{Conclusion}

COFs exposure led to the decrease of cell viability, the accumulation of ROS and NO, oxidative stress, inflammation and apoptosis. The abnormal expression of apoptosis-related proteins Bax, Bcl-2, cleaved caspase- 1 and cleaved caspase- 3 in BEAS-2B cells revealed that mitochondria-mediated intrinsic apoptosis pathway was activated. COFs increased the phosphorylation of related proteins in MAPK family JNK, ERK and p38 and led to oxidative stress (Fig. 9). COFs exposure increased the phosphorylation of IKB and promoted p 65 translocate into nuclear and activated NF-KB signaling pathway (Fig. 9). This study gave a new understanding of the toxicity of COFs on BEAS-2B cells and provided scientific data to assess its potential risks on lung disease induced by COFs.

\section{Declarations}

Authors' contributions Conceptualization, Xiangyu Cao and Jianli Liu; writing - original draft preparation, Mingyang Fu and Jingyi Miao; investigation, Yueling Sun and Rugang Zhu; statistical analysis, Chengying Liu and Ruochen Bi; writing - review and editing, Shuai Wang and Jianli Liu; funding acquisition, Xiangyu Cao and Jianli Liu. All authors have read and agreed to the published version of the manuscript.

Funding This study was supported by the Project Supported by Scientific Research Fund of Liaoning Provincial Education Department (No.LFW201903; No. LQN201714), Project Supported for Youth and Middle-aged Science and Technology Innovative Talents of Shenyang City (No.RC200137), Natural Science Foundation of Liaoning Province (No.2019-ZD-0198).

Data availability The datasets used and/or analyzed during the current study are available from the corresponding author on reasonable request. 


\section{Compliance with ethical standards}

Conflict of interest The authors declare that they have no conflicts of interest.

Ethical approval Not applicable.

Consent to participate Not applicable.

Consent to publish Not applicable.

\section{References}

1. Allen L. Robinson RS, Neil M, Donahue A, Bernardo-Bricker, Wolfgang F, Rogge (2006) Source Apportionment of Molecular Markers and Organic Aerosol. 3. Food Cooking Emissions. Environ Sci Technol 40:7820-7827. https://doi.org/10.1021/es060782h

2. Anderson HR (1979) Chronic lung disease in the Papua New Guinea Highlands. Thorax 34:647-653. https://doi.org/10.1136/thx.34.5.647

3. Aschauer L, Carta G, Vogelsang N, Schlatter E, Jennings P (2015) Expression of xenobiotic transporters in the human renal proximal tubule cell line RPTEC/TERT1. Toxicol In Vitro 30:95-105. https://doi.org/10.1016/j.tiv.2014.12.003

4. Berglund B, Knoppel BB,H, Lindvall T, Maroni M, Moihave L and p. Skov (1992) Effects of Indoor Air Pollution on Human Health. Indoor Air 2:2-25. https://doi.org/10.1111/j.1600-0668.1992.02-21.x

5. Bo N, Yilin H, Chaoyue Y, Lu L, Yuan Y (2020) Acrylamide induces NLRP3 inflammasome activation via oxidative stress- and endoplasmic reticulum stress-mediated MAPK pathway in HepG2 cells. Food Chem Toxicol 145:111679. https://doi.org/10.1016/j.fct.2020.111679

6. Cao X, Fu M, Bi R, Zheng X, Fu B, Tian S, Liu C, Li Q, Liu J (2021) Cadmium induced BEAS-2B cells apoptosis and mitochondria damage via MAPK signaling pathway. Chemosphere 263:128346. https://doi.org/10.1016/j.chemosphere.2020.128346

7. Cao X, Tian S, Fu M, Li Y, Sun Y, Liu J, Liu Y (2020a) Resveratrol protects human bronchial epithelial cells against nickel-induced toxicity via suppressing p38 MAPK, NF-kappaB signaling, and NLRP3 inflammasome activation. Environ Toxicol 35:609-618. https://doi.org/10.1002/tox.22896

8. Cao X, Wang S, Bi R, Tian S, Huo Y, Liu J (2019) Toxic effects of $\mathrm{Cr}(\mathrm{VI})$ on the bovine hemoglobin and human vascular endothelial cells: Molecular interaction and cell damage. Chemosphere 222:355363. https://doi.org/10.1016/j.chemosphere.2019.01.137

9. Cao X, Xia Y, Liu D, He Y, Mu T, Huo Y, Liu J (2020b) Inhibitory effects of Lentinus edodes mycelia polysaccharide on alpha-glucosidase, glycation activity and high glucose-induced cell damage. Carbohydr Polym 246:116659. https://doi.org/10.1016/j.carbpol.2020.116659

10. Che Z, Liu Y, Chen Y, Cao J, Liang C, Wang L, Ding R (2014) The apoptotic pathways effect of fine particulate from cooking oil fumes in primary fetal alveolar type II epithelial cells. Mutat Res Genet Toxicol Environ Mutagen 761:35-43. https://doi.org/10.1016/j.mrgentox.2014.01.004 
11. Carlisle DL, Singh DEP,J, Owens BM, Blankenship LJ, Orenstein JM, Patierno SR (2000) Apoptosis and P53 Induction in Human Lung Fibroblasts Exposed to Chromium (VI): Effect of Ascorbate and Tocopherol. Toxicol Sci 55:60-68. https://doi.org/10.1002/bit.20497

12. Deanfield JE, Halcox JP, Rabelink TJ (2007) Endothelial function and dysfunction: testing and clinical relevance. Circulation 115:1285-1295.

https://doi.org/10.1161/CIRCULATIONAHA.106.652859

13. Dhib A, Denis M, Ziadi B, Barani A, Turki S, Aleya L (2017) Assessing ultraphytoplankton and heterotrophic prokaryote composition by flow cytometry in a Mediterranean lagoon. Environ Sci Pollut Res Int 24:13710-13721. https://doi.org/10.1007/s11356-017-8939-z

14. Ding L, Sui X, Yang M, Zhang Q, Sun S, Zhu F, Cheng H, Zhang C, Chen H, Ding R, Cao J (2020) Toxicity of cooking oil fume derived particulate matter: Vitamin D3 protects tubule formation activation in human umbilical vein endothelial cells. Ecotoxicol Environ Saf 188:109905. https://doi.org/10.1016/j.ecoenv.2019.109905

15. Ebegboni VJ, Balahmar RM, Dickenson JM, Sivasubramaniam SD (2019) The effects of flavonoids on human first trimester trophoblast spheroidal stem cell self-renewal, invasion and JNK/p38 MAPK activation: Understanding the cytoprotective effects of these phytonutrients against oxidative stress. Biochem Pharmacol 164:289-298. https://doi.org/10.1016/j.bcp.2019.04.023

16. Ellegard A (1997) Tears while Cooking: An Indicator of Indoor Air Pollution and Related Health Effects in Developing Countries. Environ Res 75:12-22. https://doi.org/10.1006/enrs.1997.3771

17. Geng J, Liu H, Ge P, Hu T, Zhang Y, Zhang X, Xu B, Wang B, Xie J (2019) PM2.5 promotes plaque vulnerability at different stages of atherosclerosis and the formation of foam cells via TLR4/MyD88/NFkappaB pathway. Ecotoxicol Environ Saf 176:76-84.

https://doi.org/10.1016/j.ecoenv.2019.03.068

18. Gholinejad Z, Khadem Ansari MH, Rasmi Y (2019) Titanium dioxide nanoparticles induce endothelial cell apoptosis via cell membrane oxidative damage and p38, PI3K/Akt, NF-kappaB signaling pathways modulation. J Trace Elem Med Biol 54:27-35.

https://doi.org/10.1016/j.jtemb.2019.03.008

19. Giuseppe Cirino EDaJLW (2006) Nitric Oxide and Inflammation. Inflammation Allergy: Drug Targets 5:115-119. https://doi.org/10.2174/187152806776383143

20. Gonzalez-Martin J, Kraakman NJR, Perez C, Lebrero R, Munoz R (2021) A state-of-the-art review on indoor air pollution and strategies for indoor air pollution control. Chemosphere 262:128376. https://doi.org/10.1016/j.chemosphere.2020.128376

21. Guo H, Ji J, Wei K, Sun J, Zhang Y, Sun X (2021a) MAPK/AP-1 and ROS participated in ratio- and time-dependent interaction effects of deoxynivalenol and cadmium on HT-29 cells. Food Chem Toxicol 148:111921. https://doi.org/10.1016/j.fct.2020.111921

22. Guo H, Jian Z, Liu H, Cui H, Deng H, Fang J, Zuo Z, Wang X, Zhao L, Geng Y, Ouyang P, Tang H (2021b) TGF-beta1-induced EMT activation via both Smad-dependent and MAPK signaling 
pathways in Cu-induced pulmonary fibrosis. Toxicol Appl Pharmacol 418:115500.

https://doi.org/10.1016/j.taap.2021.115500

23. Hammadi A, Billard C, Faussat AM, Kolb JP (2008) Stimulation of iNOS expression and apoptosis resistance in B-cell chronic lymphocytic leukemia (B-CLL) cells through engagement of Toll-like receptor 7 (TLR-7) and NF-kappaB activation. Nitric Oxide 19:138-145.

https://doi.org/10.1016/j.niox.2008.04.017

24. Hou J, Sun H, Zhou Y, Zhang Y, Yin W, Xu T, Cheng J, Chen W, Yuan J (2018) Environmental exposure to polycyclic aromatic hydrocarbons, kitchen ventilation, fractional exhaled nitric oxide, and risk of diabetes among Chinese females. Indoor Air 28:383-393. https://doi.org/10.1111/ina.12453

25. Ingo Schmitz SK, Peter H, Krammer (2000) Regulation of death receptor -mediated apoptosis pathways. Int J Biochem Cell Biol 32:1123-1136. https://doi.org/10.1016/S1357-2725(00)00048-0

26. Jonathan M. Samet MD (1993) Indoor Air Pollution: A Public Health Perspective. Indoor Air 3:219226. https://doi.org/10.1111/j.1600-0668.1993.00002.x

27. Juntarawijit $Y$, Juntarawijit C (2019) Cooking smoke exposure and respiratory symptoms among those responsible for household cooking: A study in Phitsanulok. Thailand Heliyon 5:e01706. https://doi.org/10.1016/j.heliyon.2019.e01706

28. Kirk R, Smith JMS, Romieu I, Nigel Bruce (2000) Indoor air pollution in developing countries and acute lower respiratory infections in children. Thorax 55:518-532.

http://dx.doi.org/10.1136/thorax.55.6.518

29. Krishnaswamy Kannan SKJ (2000) Oxidative stress and apoptosis. Pathophysiology 7(27):153163. http://doi.org/10.1016/S0928-4680(00)00053-5

30. Kulyar MF, Yao W, Ding Y, Du H, Li K, Zhang L, Li A, Huachun P, Waqas M, Mehmood K, Li J (2021) Cluster of differentiation 147 (CD147) expression is linked with thiram induced chondrocyte's apoptosis via Bcl-2/Bax/Caspase-3 signalling in tibial growth plate under chlorogenic acid repercussion. Ecotoxicol Environ Saf 213:112059. http://doi.org/10.1016/j.ecoenv.2021.112059

31. Lai CH, Jaakkola JJ, Chuang CY, Liou SH, Lung SC, Loh CH, Yu DS, Strickland PT (2013) Exposure to cooking oil fumes and oxidative damages: a longitudinal study in Chinese military cooks. J Exposure Sci Environ Epidemiol 23:94-100. http://doi.org/10.1038/jes.2012.87

32. Lee S-H, Kang S-M, Ko S-C, Kang M-C, Jeon Y-J (2013) Octaphlorethol A, a novel phenolic compound isolated from Ishige foliacea, protects against streptozotocin-induced pancreatic $\beta$ cell damage by reducing oxidative stress and apoptosis. Food Chem Toxicol 59:643-649. http://doi.org/10.1016/j.fct.2013.07.011

33. Lee T, Gany F (2013) Cooking oil fumes and lung cancer: a review of the literature in the context of the U.S. population. J Immigr Minor Healt 15:646-652. http://doi.org/10.1007/s10903-012-9651-1

34. Li S, Liu H, Zhou Z, Cao Y (2020) Titanate nanotubes at non-cytotoxic concentrations affect NO signaling pathway in human umbilical vein endothelial cells. Toxicol In Vitro 62, 104689. http://doi.org/ 10.1016/j.tiv.2019.104689 
35. Liu J, Wang S, Tian S, He Y, Lou H, Yang Z, Kong Y, Cao X (2018) Nobiletin inhibits breast cancer via p38 mitogen-activated protein kinase, nuclear transcription factor-kappaB, and nuclear factor erythroid 2-related factor 2 pathways in MCF-7 cells. Food Nutr Res 62:1323-1333. http://doi.org/10.29219/fnr.v62.1323

36. Liu Z, Li J, Rommel J, Feng S (2020) Health impacts of cooking fuel choice in rural China. Energy Econ 89:104811. http://doi.org/10.1016/j.eneco.2020.104811

37. Ma Y, Deng L, Ma P, Wu Y, Yang X, Xiao F, Deng Q (2021) In vivo respiratory toxicology of cooking oil fumes: Evidence, mechanisms and prevention. J Hazard Mater 402:123455.

http://doi.org/10.1016/j.jhazmat.2020.123455

38. Maggie Bargouti MV, Hui Liu SS, Zughaier, Louisa F, Titus SD, Boden (2009) 641. LMP-1 Inhibits Toll like Receptor/NFKB Induced iNOS Synthase; a Possible Role in Modulating the Innate Immune Response. Mol Ther 17(S1). http://doi.org/10.1016/s1525-0016(16)38999-7

39. Mehta S, Dhawan V (2020) Molecular insights of cigarette smoke condensate-activated NLRP3 inflammasome in THP-1 cells in a stage-specific atherogenesis. Int Immunopharmacol 88:107013. http://doi.org/10.1016/j.intimp.2020.107013

40. Nathan C, Ding A (2010) Nonresolving inflammation. Cell 140:871-882. http://doi.org/10.1016/j.cell.2010.02.029

41. Park EJ, Choi J, Park YK, Park K (2008) Oxidative stress induced by cerium oxide nanoparticles in cultured BEAS-2B cells. Toxicology 245:90-100. http://doi.org/10.1016/j.tox.2007.12.022

42. Park EJ, Park K (2009) Induction of pro-inflammatory signals by 1-nitropyrene in cultured BEAS-2B cells. Toxicol Lett 184:126-133. http://doi.org/10.1016/j.toxlet.2008.10.028

43. Park JY, Cho HY, Kim JK, Noh KH, Yang JR, Ahn JM, Lee MO, Song YS (2005) Chlorella dichloromethane extract ameliorates NO production and iNOS expression through the downregulation of NF kappa B activity mediated by suppressed oxidative stress in RAW 264.7 macrophages. Clin Chim Acta 351:185-196. http://doi.org/10.1016/j.cccn.2004.09.013

44. Pinkerton JW, Kim RY, Robertson AAB, Hirota JA, Wood LG, Knight DA, Cooper MA, O'Neill LAJ, Horvat JC, Hansbro PM (2017) Inflammasomes in the lung. Mol Immunol 86:44-55. http://doi.org/10.1016/j.molimm.2017.01.014

45. Schlereth T, Drummond PD, Birklein F (2014) Inflammation in CRPS: role of the sympathetic supply. Auton Neurosci 182:102-107. http://doi.org/10.1016/j.autneu.2013.12.011

46. Sjaastad AK, Jorgensen RB, Svendsen K (2010) Exposure to polycyclic aromatic hydrocarbons (PAHs), mutagenic aldehydes and particulate matter during pan frying of beefsteak. Occup Environ Med 67:228-232. http://doi.org/10.2307/27797742

47. Sjaastad AK, Svendsen K (2009) Exposure to polycyclic aromatic hydrocarbons (PAHs), mutagenic aldehydes, and particulate matter in Norwegian a la carte restaurants. Ann Occup Hyg 53:723-729. http://doi.org/10.1093/annhyg/mep059

48. Smith KR (2002) Indoor air pollution in developing countries: recommendations for research. Indoor Air 12:198-207. http://doi.org/10.1034/j.1600-0668.2002.01137.x 
49. Sofuoglu SC, Toprak M, Inal F, Cimrin AH (2015) Indoor air quality in a restaurant kitchen using margarine for deep-frying. Environ Sci Pollut Res Int 22:15703-15711. http://doi.org/10.1007/s11356-015-4762-6

50. Son YO, Hitron JA, Wang X, Chang Q, Pan J, Zhang Z, Liu J, Wang S, Lee JC, Shi X (2010) Cr(VI) induces mitochondrial-mediated and caspase-dependent apoptosis through reactive oxygen speciesmediated p53 activation in JB6 Cl41 cells. Toxicol Appl Pharmacol 245:226-235. http://doi.org/10.1016/j.taap.2010.03.004

51. Svendsen K, Jensen HN, Sivertsen I, Sjaastad AK (2002) Exposure to cooking fumes in restaurant kitchens in norway. Ann Occup Hyg 46:395-400. http://doi.org/10.1093/annhyg/mef045

52. van der Stel W, Carta G, Eakins J, Darici S, Delp J, Forsby A, Bennekou SH, Gardner I, Leist M, Danen EHJ, Walker P, van de Water B, Jennings $P$ (2020) Multiparametric assessment of mitochondrial respiratory inhibition in HepG2 and RPTEC/TERT1 cells using a panel of mitochondrial targeting agrochemicals. Arch Toxicol 94:2707-2729. http://doi.org/10.1007/s00204-020-02792-5

53. Vavalà T, Giaj Levra M, Novello S (2014) Lung cancer in never smokers: a different disease. Curr Respir Care Rep 3:26-34. http://doi.org/10.1007/s13665-013-0071-z

54. Wang L, Hu W, Guan Q, Du G, Chen T, Wu W, Wang Y, Wang X, Xia Y (2018) The association between cooking oil fume exposure during pregnancy and birth weight: A prospective mother-child cohort study. Sci Total Environ 612:822-830. http://doi.org/10.1016/j.scitotenv.2017.08.031

55. Wang L, Li X, Yang Z, Zhu M, Xie J (2019) Autophagy induced by low concentrations of crotonaldehyde promotes apoptosis and inhibits necrosis in human bronchial epithelial cells. Ecotoxicol Environ Saf 167:169-177. http://doi.org/10.1016/j.ecoenv.2018.10.008

56. Wang W, Deng Z, Feng Y, Liao F, Zhou F, Feng S, Wang X (2017) PM2.5 induced apoptosis in endothelial cell through the activation of the p53-bax-caspase pathway. Chemosphere 177:135-143. http://doi.org/10.1016/j.chemosphere.2017.02.144

57. Wang Y, Huang C, Bian E, Lei T, Lv X, Li J (2020) NLRC5 negatively regulates inflammatory responses in LPS-induced acute lung injury through NF-kappaB and p38 MAPK signal pathways. Toxicol Appl Pharmacol 403:115150. http://doi.org/10.1016/j.taap.2020.115150

58. William Y, Park RBG, Kenneth P, Steinberg JT, Ruzinski, Frank Radella II, Park DR, Shawn JP, Skerrett J, Hudson LD, Thomas R, Martin (2001) Cytokine Balance in the Lungs of Patients with Acute Respiratory Distress Syndrome. Am J Respir Crit Care Med 164:1896-1903. http://doi.org/10.1164/ajrccm.164.10.2104013

59. Wu M-T, Lee L-H, Ho C-K, Wu S-C, Lin L-Y, Cheng B-H, Liu C-L, Yang C-Y, Tsai H-T, Wu T-N (2004) Environmental exposure to cooking oil fumes and cervical intraepithelial neoplasm. Environ Res 94:25-32. https://doi.org/10.1016/S0013-9351(03)00118-X

60. Wu SC, Yen GC (2004) Effects of cooking oil fumes on the genotoxicity and oxidative stress in human lung carcinoma (A-549) cells. Toxicol In Vitro 18:571-580. https://doi.org/10.1016/j.tiv.2004.01.004 
61. Yan C, Zhang L, Lu B, Lyu D, Chen H, Song F, Wang X, Chen Z, Fu Q, Yao K (2020) Trans, trans-2,4decadienal (tt-DDE), a composition of cooking oil fumes, induces oxidative stress and endoplasmic reticulum stress in human corneal epithelial cells. Toxicol In Vitro 68:104933.

https://doi.org/10.1016/j.tiv.2020.104933

62. Yang F, Pei R, Zhang Z, Liao J, Yu W, Qiao N, Han Q, Li Y, Hu L, Guo J, Pan J, Tang Z (2019) Copper induces oxidative stress and apoptosis through mitochondria-mediated pathway in chicken hepatocytes. Toxicol In Vitro 54:310-316. https://doi.org/10.1016/j.tiv.2018.10.017

63. Yao Y, Chen X, Chen W, Wang Q, Fan Y, Han Y, Wang T, Wang J, Qiu X, Zheng M, Que C, Zhu T (2021) Susceptibility of individuals with chronic obstructive pulmonary disease to respiratory inflammation associated with short-term exposure to ambient air pollution: A panel study in Beijing. Sci Total Environ 766:142639. https://doi.org/10.1016/j.scitotenv.2020.142639

64. Zhong X, He J, Zhang X, Li C, Tian X, Xia W, Gan H, Xia Y (2019) UCP2 alleviates tubular epithelial cell apoptosis in lipopolysaccharide-induced acute kidney injury by decreasing ROS production. Biomed Pharmacother 115:108914. https://doi.org/10.1016/j.biopha.2019.108914

65. Zhu F, Cheng H, Lei R, Shen C, Liu J, Hou L, Zhang C, Xu Y, Ding R, Cao J (2019) Effects of cooking oil fume derived fine particulate matter on blood vessel formation through the VEGF/VEGFR2/MEK1/2/ERK1/2/mTOR pathway in human umbilical vein endothelial cells. Environ Toxicol Pharmacol 69:112-119. https://doi.org/10.1016/j.etap.2019.04.008

\section{Figures}

A
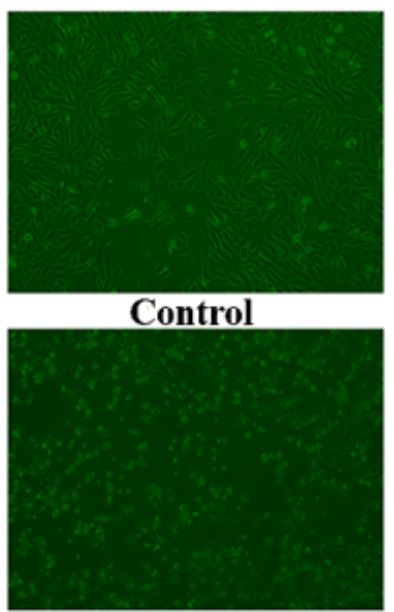

24h

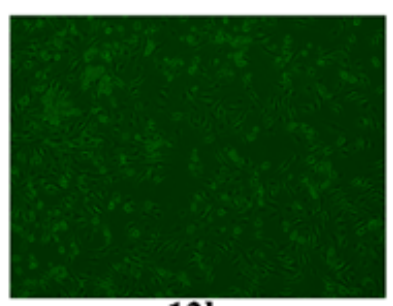

$12 \mathrm{~h}$

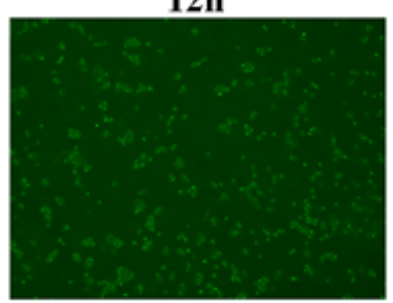

$48 \mathrm{~h}$

\section{B}

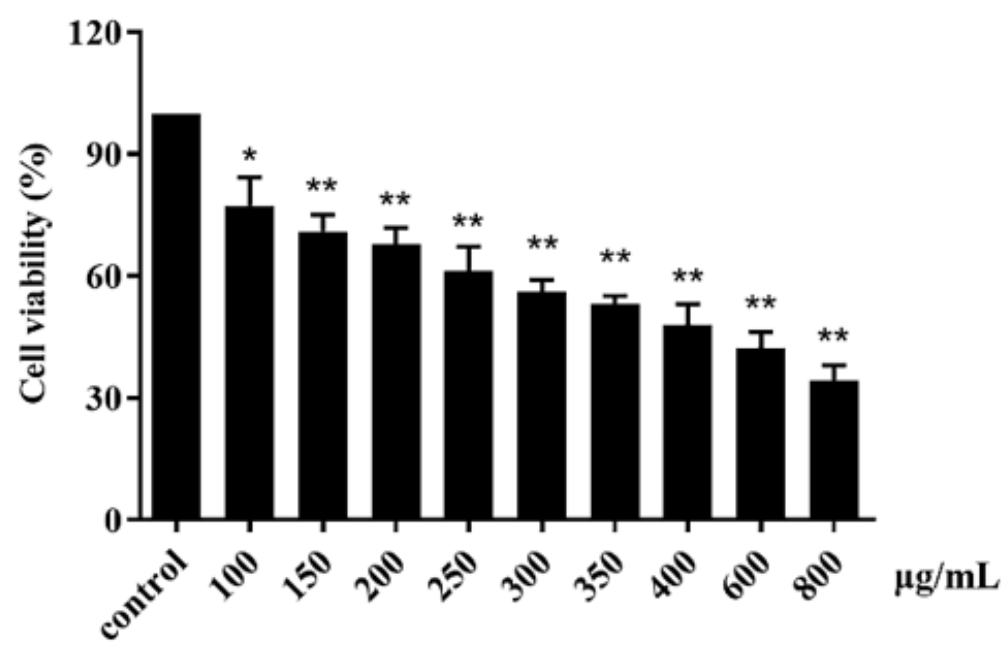

\section{Figure 1}

Effect of COFs on the viability of Beas-2B cells. Data were expressed as means \pm SD from three independent experiments. ${ }^{*} p<0.05,{ }^{*} p<0.01$ compared with the control group. 
A
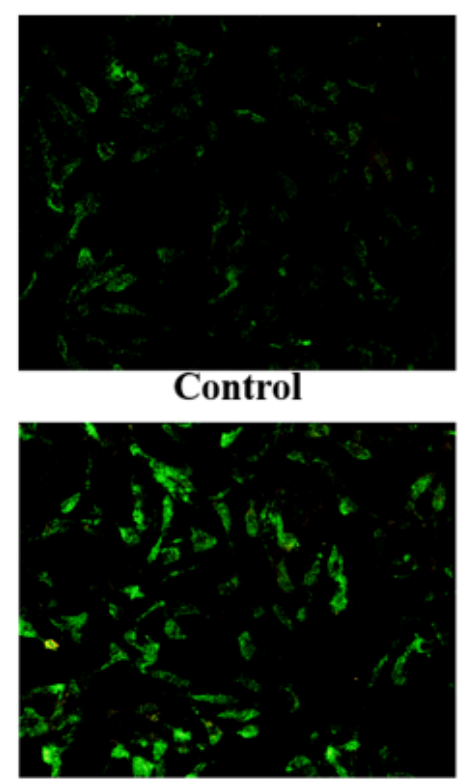

$400 \mu \mathrm{g} / \mathrm{mL}$

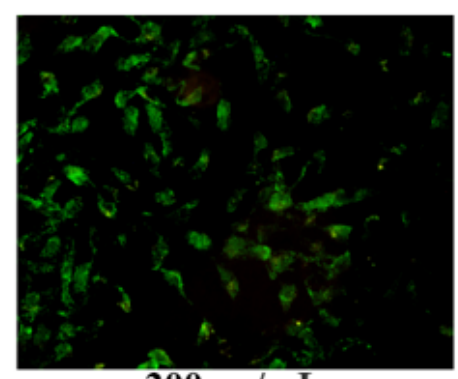

$200 \mu \mathrm{g} / \mathrm{mL}$

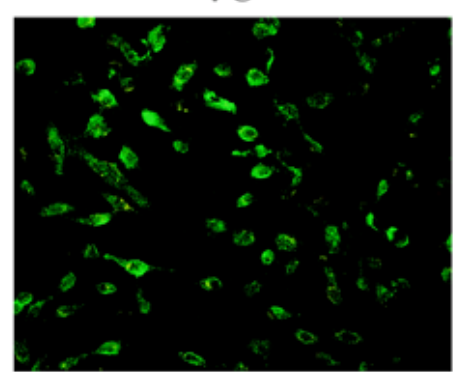

$600 \mu \mathrm{g} / \mathrm{mL}$

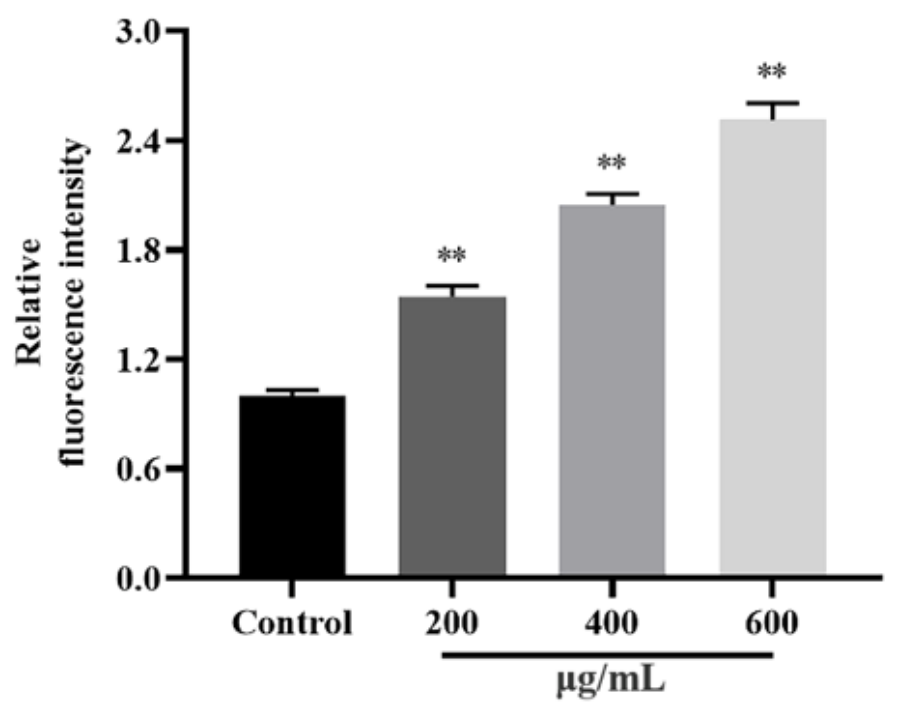

Figure 2

Effect of COFs on ROS levels of Beas-2B cells. Data were expressed as mean \pm SD of three independent experiments. ${ }^{* *} p<0.01$ compared with the control group.

A
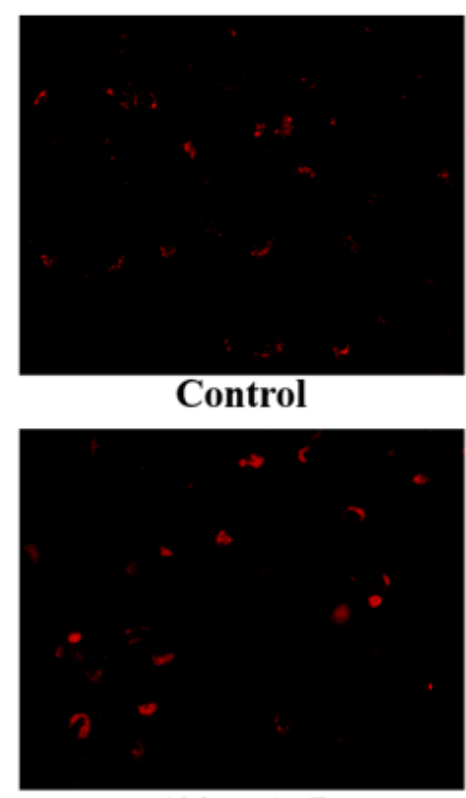

$400 \mu \mathrm{g} / \mathrm{mL}$
B

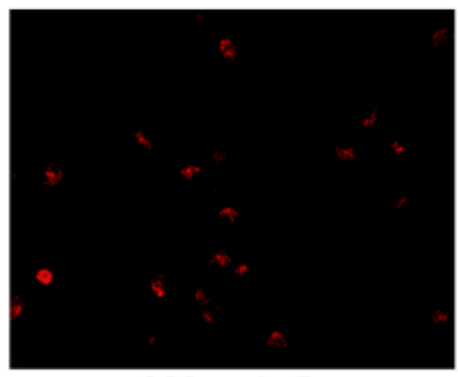

$200 \mu \mathrm{g} / \mathrm{mL}$

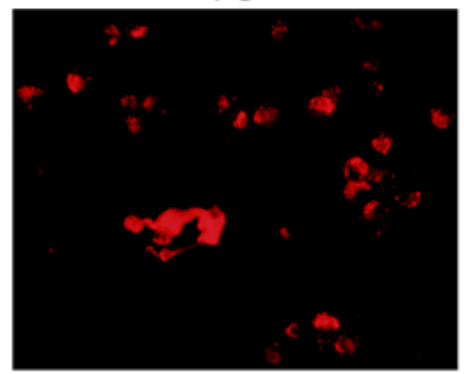

$600 \mu \mathrm{g} / \mathrm{mL}$

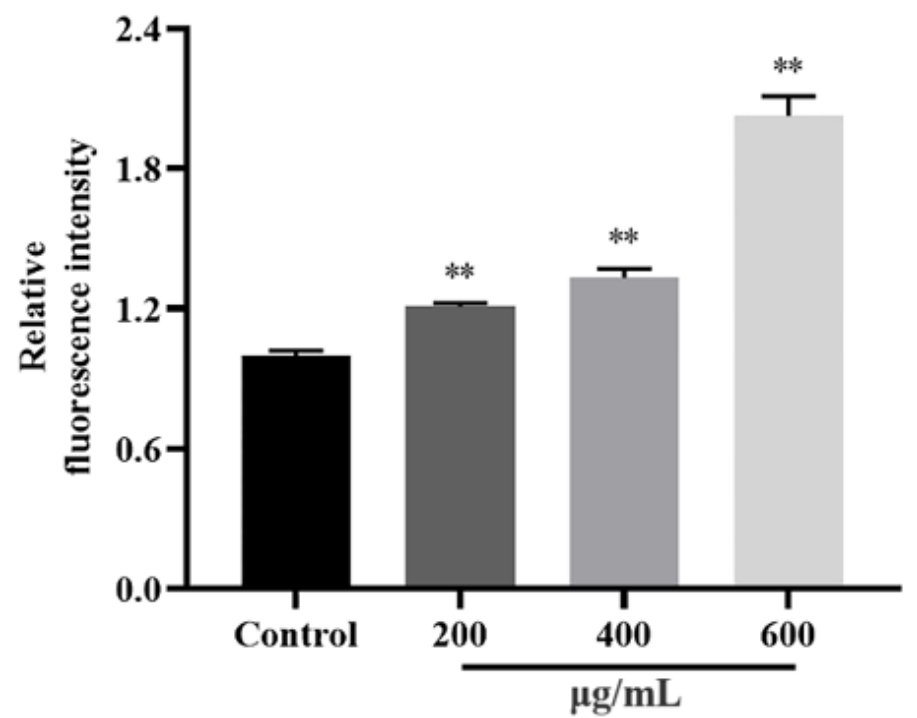

Figure 3 
Effect of COFs on the levels of NO in Beas-2B cells. Data were expressed as mean \pm SD of three independent experiments. ${ }^{\star *} p<0.01$ compared with the control group.

A

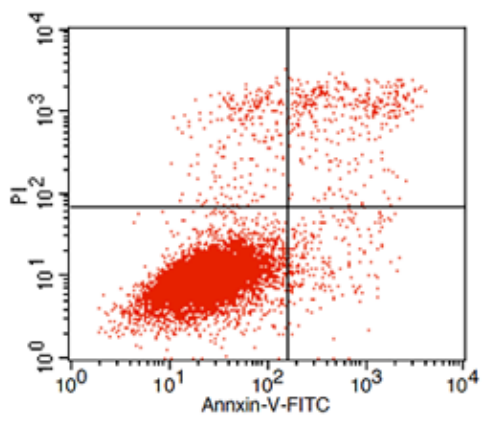

Control

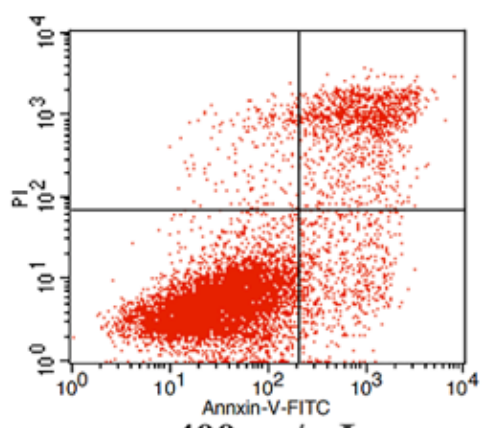

$400 \mu \mathrm{g} / \mathrm{mL}$
B

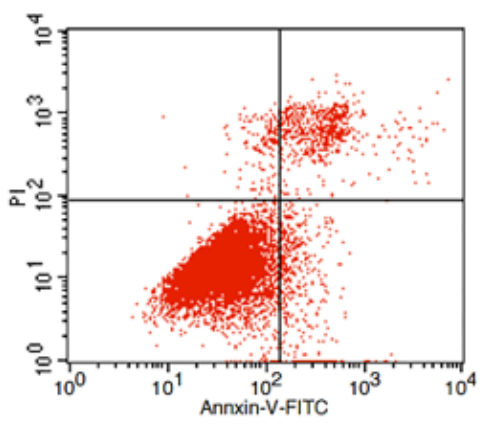

$200 \mu \mathrm{g} / \mathrm{mL}$

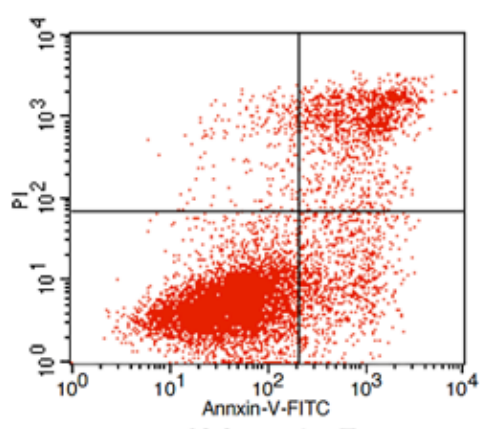

$600 \mu \mathrm{g} / \mathrm{mL}$

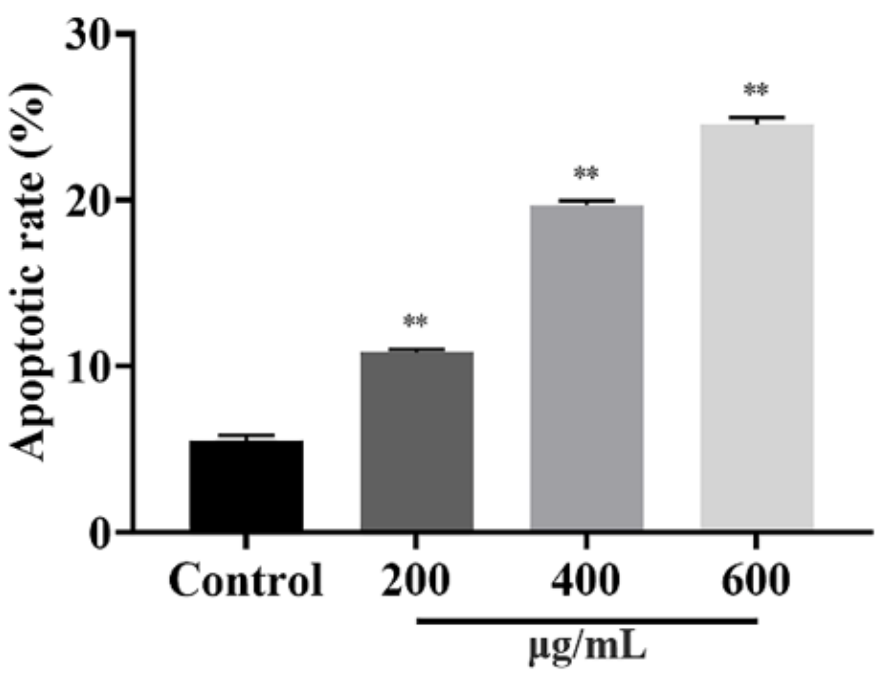

\section{Figure 4}

Effect of COFs on cell apoptosis of Beas-2B cells. Data were expressed as mean \pm SD of three independent experiments. ${ }^{*} p<0.01$ compared with the control group. 


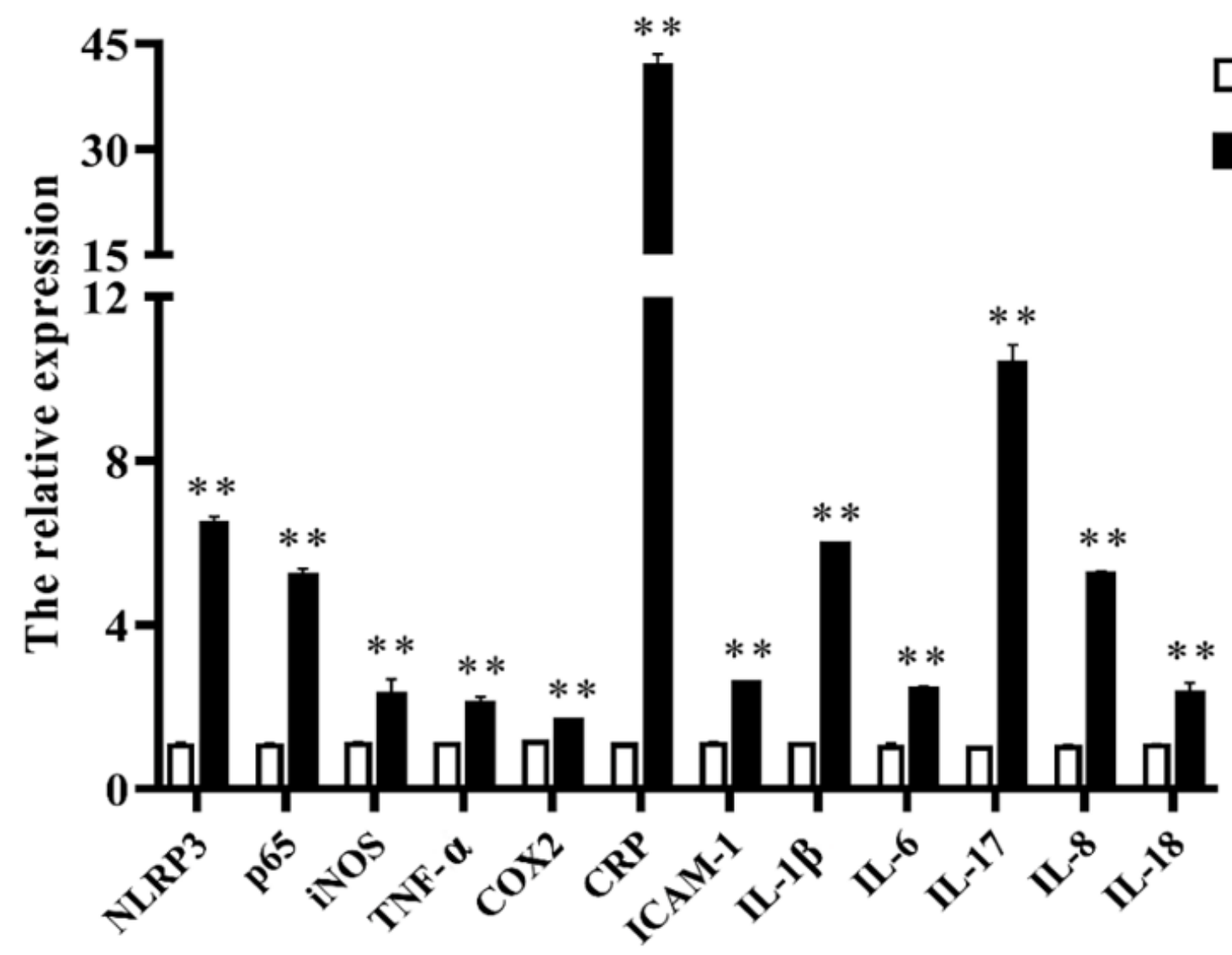

Figure 5

COFs induced Beas-2B cells inflammation. The mRNA expression of NLRP3, p65, iNOS, TNF- $a$, COX2, CRP,

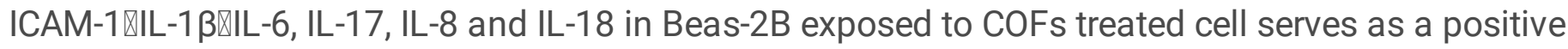
control group. Data were expressed as means \pm SD from three independent experiments. ${ }^{*} p<0.01$ compared with the control group.

A

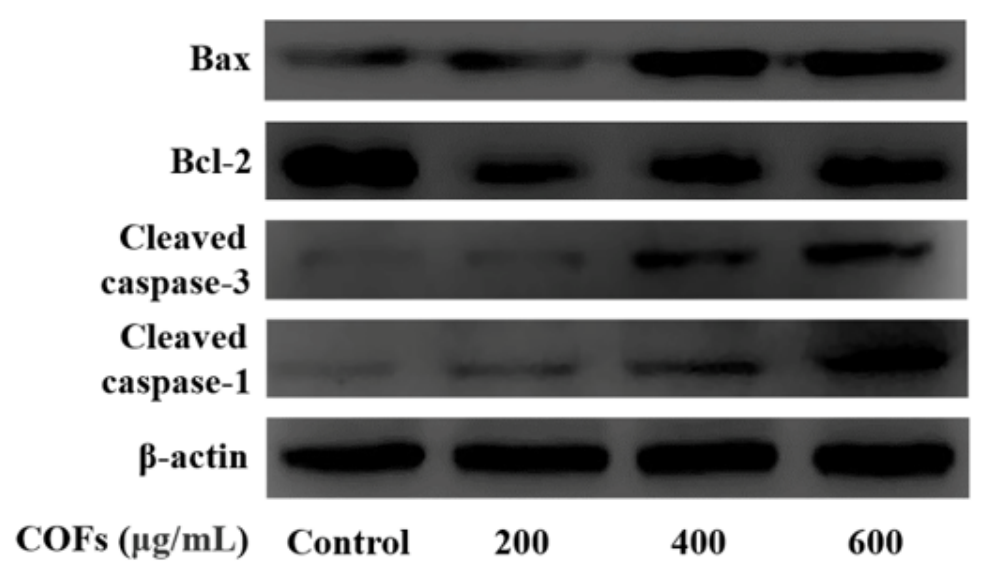

B

Bax/Bcl-2

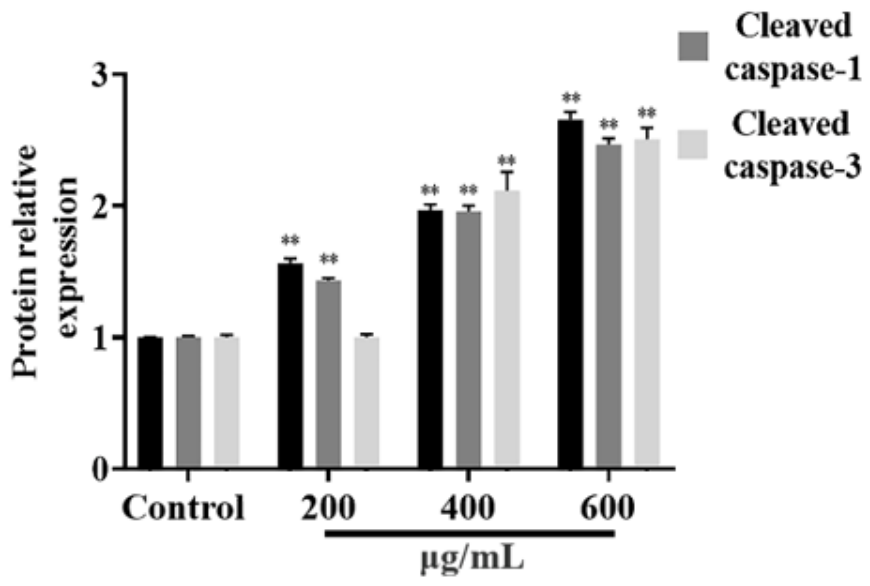


Figure 6

COFs regulated the expression of apoptosis-associated proteins Bax, Bcl-2, cleaved caspase-1 and cleaved caspase-3. Data were expressed as mean \pm SD of three independent experiments. ${ }^{* \star} p<0.01$ compared with the control group.

A

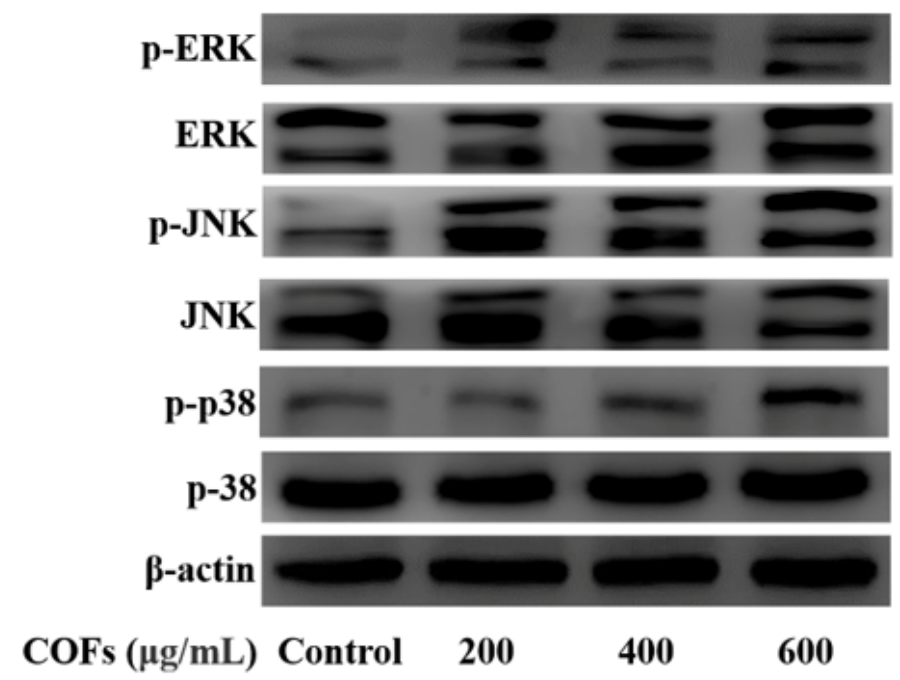

B

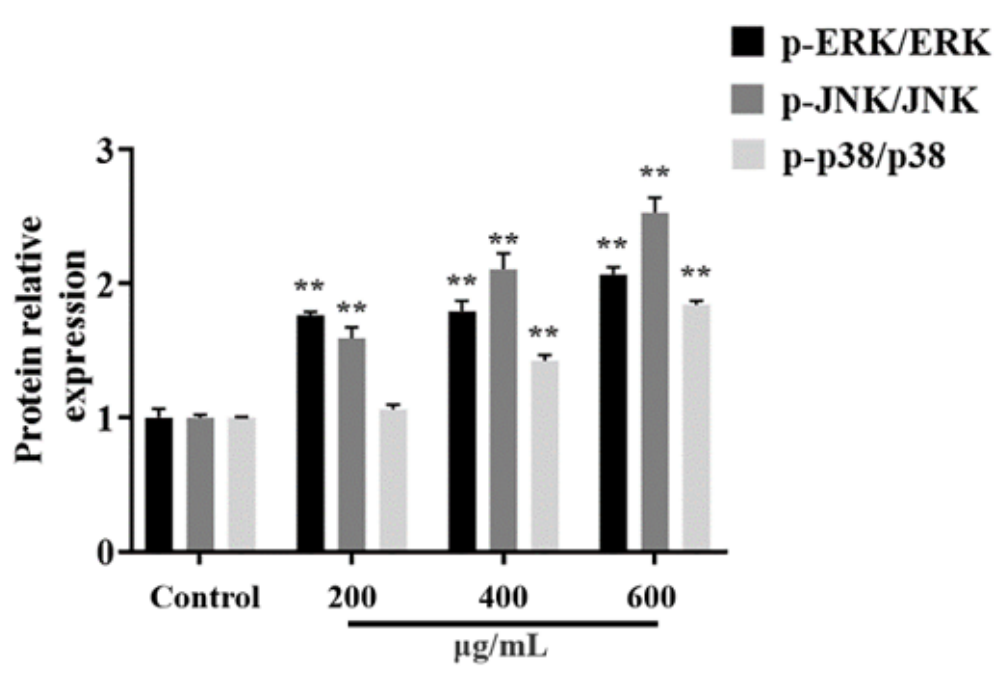

\section{Figure 7}

Effects of COFs on MAPK signaling pathway in Beas-2B cells. (A). Western blot analysis of protein expression of ERK, JNK and p38 protein. (B). COFs increased the protein expression of phosphorylation ERK, JNK and p38. Data were expressed as mean \pm SD of three independent experiments. ${ }^{*} \mathrm{p}<0.01$ compared with the control group.

A

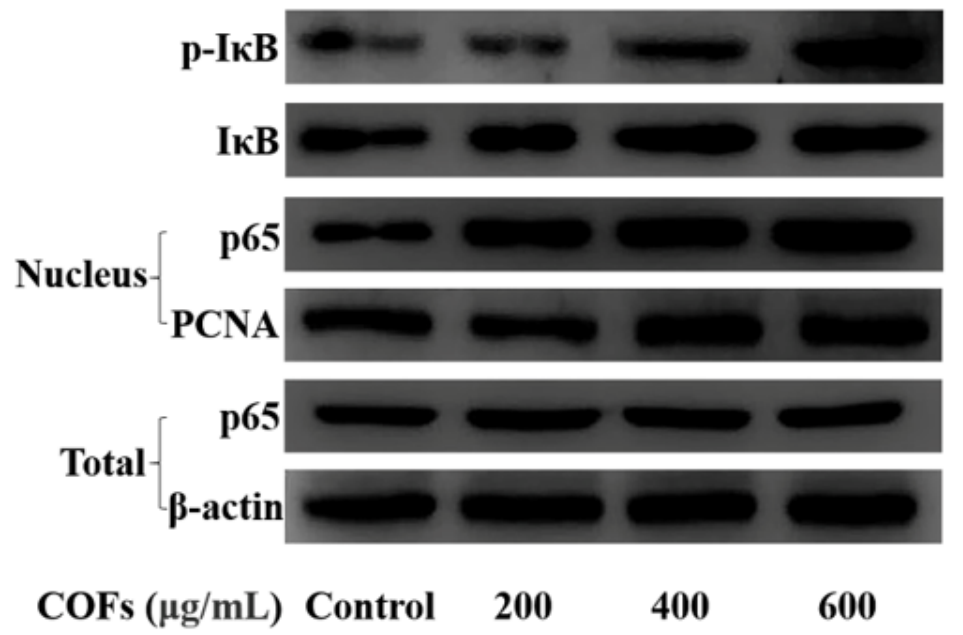

B

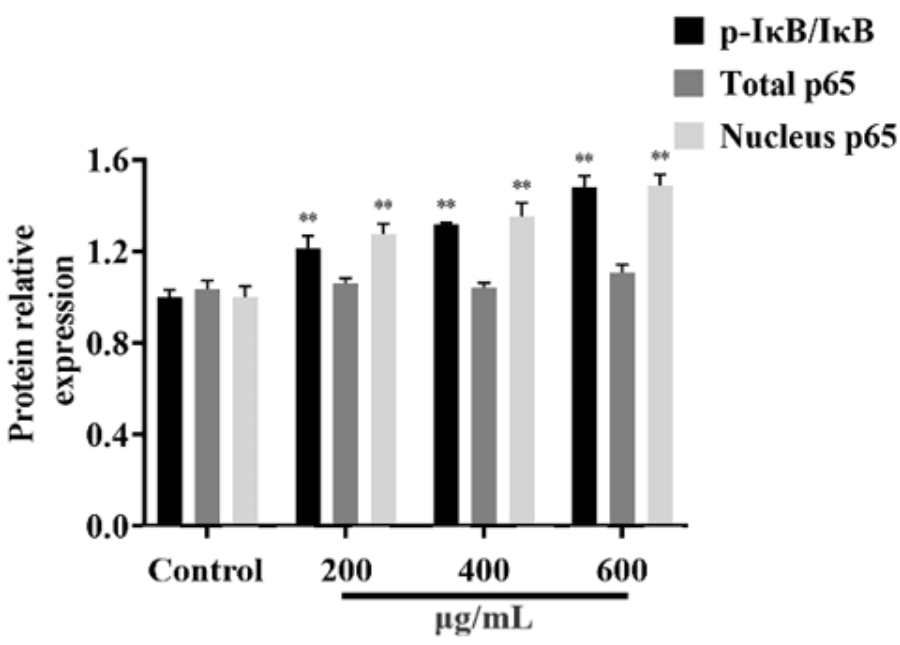

Figure 8 

expressed as mean \pm SD of three independent experiments. ${ }^{\star \star} p<0.01$ compared with the control group.

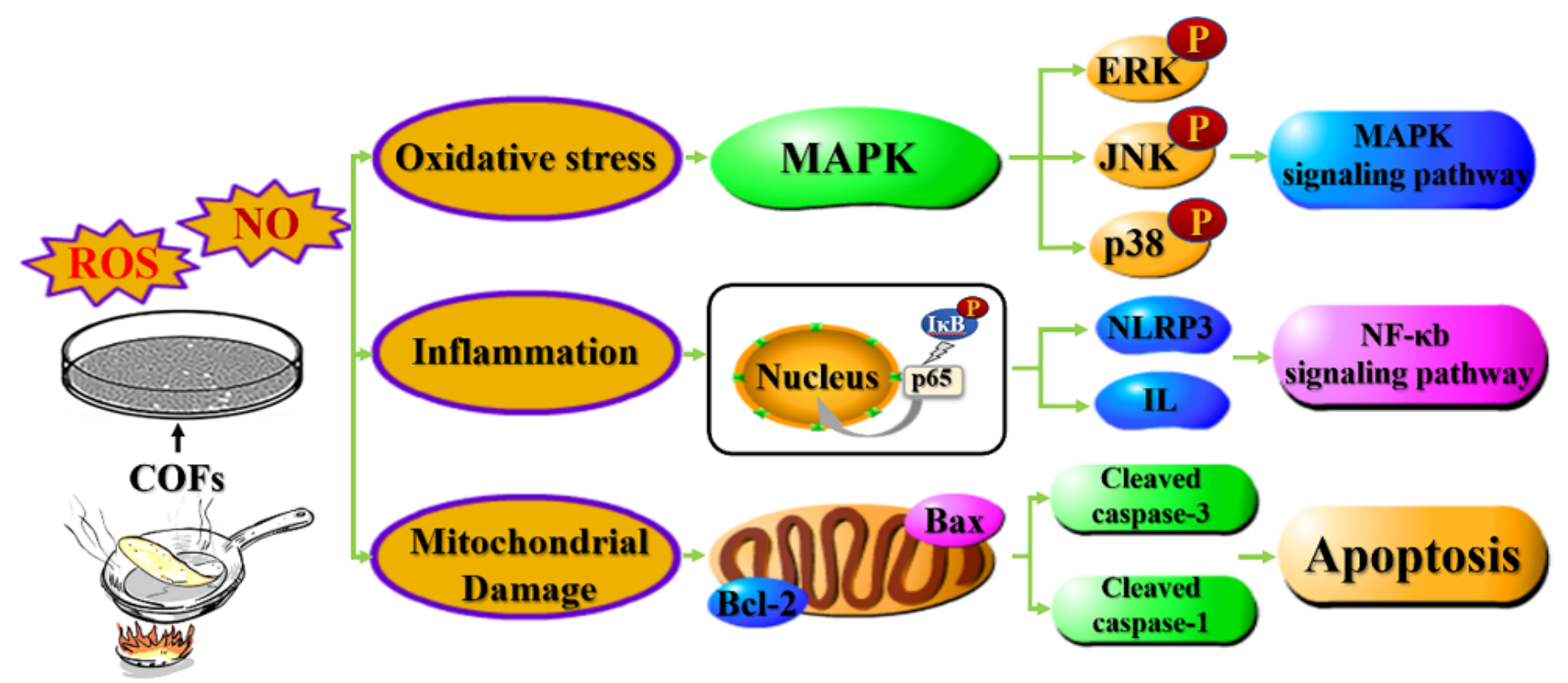

Figure 9

COFs induced BEAS-2B cells damage through oxidative stress, inflammation and activated mitochondriamediated intrinsic apoptosis pathway. 